\title{
Hubungan Komunikasi Terapeutik Perawat dengan Kepuasan Pasien Rawat I nap di Rumah Sakit
}

\author{
Cica Daryanti ${ }^{1}$, Slamet Priyono ${ }^{2}$ \\ 1,2Program Sarjana Kesehatan Masyarakat, Sekolah Tinggi IImu Kesehatan Indonesia Maju \\ Jl. Harapan Nomor 50, Lenteng Agung - Jakarta Selatan 12610, Telp: (021) 78894045 \\ Email: ${ }^{1}$ cicadaryanti@gmail.com, ${ }^{2}$ slametpriy75@gmail.com
}

\begin{abstract}
Abstrak
Komunikasi terapeutik yang baik akan menciptakan hubungan saling percaya antara perawat dan pasien. Dengan demikian, pasien akan merasa puas dan nyaman terhadap pelayanan yang diberikan perawat sehingga meningkatkan semangat dan motivasi pasien untuk sembuh. Tujuan penelitian ini adalah untuk mengetahui hubungan komunikasi terapeutik perawat dengan kepuasan pasien rawat inap di Rumah Sakit Grha Permata lbu Depok tahun 2016. Jenis penelitian kuantitatif dengan desain penelitian Cross Sectional. Populasi dalam penelitian ini adalah seluruh pasien rawat inap di Rumah Sakit Grha Permata lbu Depok. Pengambilan sampel dengan menggunakan accidental sampling, maka didapatkan jumlah sampel dalam penelitian ini sebanyak 40 responden. Instrument penelitian menggunakan kuesioner dan pengolahan data menggunakan program. Hasil penelitian diperoleh dari 40 responden sebanyak 24 responden merasa puas dengan pelayanan rawai inap dan sebanyak 23 responden menilai komunikasi terapeutik perawat baik. Uji hipotesis chi square antara komunikasi terapeutik perawat terhadap kepuasan pasien rawat inap di Rumah Sakit Grha Permata lbu Depok diperoleh p-value sebesar 0,016 dan nilai Odds Ratio (OR) sebesar 6,600. Kesimpulan penelitian ini ada hubungan komunikasi terapeutik perawat terhadap kepuasan pasien rawat inap di Rumah Sakit Grha Permata Ibu Depok tahun 2016. Diharapkan manajemen atau Diklat Rumah Sakit Grha Permata lbu Depok untuk mendukung serta memfasilitasi perawat dalam meningkatkan komunikasi terapeutiknya, dengan mengirimkan perawatnya dalam pelatihan, workshop, bimbingan teknis khusus maupun seminar mengenai komunikasi terapeutik yang baik.
\end{abstract}

Kata kunci : Kepuasan, Komunikasi, Pasien, Perawat, Terapeutik

\begin{abstract}
Good therapeutic communication will create a relationship of trust between nurses and patients. Thus, the patient will feel satisfied and comfortable with the services provided nurses to improve morale and motivation of the patient to recover. The purpose of this study was to determine the relationship of therapeutic communication nurse with patient satisfaction in hospital Grha Permata lbu Depok 2016. Type quantitative research with cross sectional study design. The population in this study were all patients at the Hospital Grha Permata lbu Depok. Sampling by using accidental sampling, so he found the number of samples in this study were 40 respondents. Instrument research using questionnaires and data processing. Results were obtained from 40 respondents were 24 respondents were satisfied with the service longline hospitalization and as many as 23 respondents assess therapeutic communication nurse well. Chi square hypothesis test between therapeutic communication nurse to patient satisfaction in hospital Grha Permata Ibu Depok obtained p-value of 0.016 and the value Odds Ratio $(O R)$ of 6.600. In conclusion, there is a relationship of communication therapeutic nurse to patient satisfaction in hospital Grha Permata lbu Depok in 2016. It is expected that the management or Training Hospital Grha Permata lbu Depok to support and facilitate nurses in improving the therapeutic communication, by sending a nurse in training, workshop, specialized technical assistance and seminars on good therapeutic communication.

Keywords : Satisfaction, Communication, Patient, Nurse, Therapeutic
\end{abstract}




\section{Pendahuluan}

Pelayanan kesehatan di rumah sakit merupakan bentuk pelayanan yang diberikan kepada pasien oleh suatu tim multi disiplin termasuk tim keperawatan. Tim keperawatan merupakan anggota tim kesehatan garda depan yang menghadapi masalah kesehatan pasien selama 24 jam secara terus menerus. Tim pelayanan keperawatan memberikan pelayanan kepada pasien sesuai dengan keyakinan profesi dan standar yang ditetapkan. Hal ini ditujukan agar pelayanan keperawatan yang diberikan senantiasa merupakan pelayanan yang aman serta dapat memenuhi kebutuhan dan harapan pasien. ${ }^{1}$ Sebagai penyedia pelayanan kesehatan, rumah sakit bersaing dalam memberikan pelayanan kesehatan yang bermutu. Rumah sakit yang mampu bertahan dalam persaingan adalah rumah sakit yang berorientasi pada kepuasan pasien. ${ }^{2}$

Pelayanan keperawatan merupakan bagian integral dari pelayanan kesehatan dirumah sakit, yang mempunyai peranan besar terhadap pencapaian efisiensi, mutu, dan citra rumah sakit dimata masyarakat. ${ }^{2}$ Pasien menginginkan perawat yang melayaninya memiliki sikap baik, murah senyum, sabar, mampu berbahasa yang mudah difahami, serta berkeinginan menolong yang tulus dan mampu menghargai pasien dan pendapatnya. Mereka mengharapkan perawat memiliki pengetahuan yang memadai tantang kondisi penyakitnya sehingga perawat mampu mengatasi setiap keluhan yang dialami oleh individual pasien. ${ }^{1}$

Untuk itu perawat memerlukan keterampilan khusus yang mencakup keterampilan intelektual, teknikal yang tercermin dalam perilaku berkomunikasi secara terapeutik dengan orang lain. ${ }^{3}$ Perawat yang memiliki keterampilan berkomunikasi secara terapeutik tidak akan hanya mudah menjalin hubungan rasa percaya dengan klien, tetapi juga mencegah terjadinya masalah legal, memberikan kepuasan profesional dalam pelayanan keperawatan, dan meningkatkan citra profesi serta citra Rumah Sakit. $^{4}$

Salah satu hal yang dilakukan perawat dalam menjaga kerjasama yang baik dengan pasien dalam membantu memenuhi kebutuhan kesehatan pasien, maupun dengan tenaga kesehatan lain dalam rangka membantu mengatasi masalah pasien adalah dengan berkomunikasi. Dengan berkomunikasi perawat dapat mendengarkan perasaan pasien dan menjelaskan prosedur tindakan keperawatan. Hubungan saling memberi dan menerima antara perawat dan pasien dalam pelayanan keperawatan disebut sebagai komunikasi terapeutik perawat yang merupakan komunikasi profesional perawat. ${ }^{4}$

Komunikasi tidak hanya sekedar alat untuk berbicara dengan klien, namun komunikasi antarperawat dan klien memiliki hubungan terapeutik yang bertujuan untuk kesembuhan klien. $^{5}$ Perawat yang memiliki keterampilan berkomunikasi terapeutik tidak saja akan mudah membina hubungan saling percaya dengan klien, tetapi juga dapat mencegah terjadinya masalah legal etik, serta dapat memberikan kepuasan profesional dalam pelayanan keperawatan, meningkatkan citra profesi keperawatan dan citra rumah sakit dalam memberikan pelayanan. Ada dua jenis komunikasi yaitu komunikasi verbal, dan komunikasi non verbal yang dimanifestasikan secara terapeutik. Pemberian asuhan keperawatan khususnya yang berada di pelayanan kesehatan sangat diperlukan adanya strategi pelaksanaan tindakan keperawatan yang dilaksanakan setiap hari. Adapun strategi yang dimaksud adalah strategi komunikasi terapeutik. Strategi tersebut dapat dilakukan oleh perawat. ${ }^{6}$

Ada beberapa kemungkinan kurang berhasilnya komunikasi terapeutik perawat pada klien diantaranya dipengaruhi oleh kurangnya pengetahuan perawat dalam komunikasi terapeutik, sikap perawat, tingkat pendidikan, pengalaman, lingkungan, jumlah tenaga yang kurang dan lain-lain. Rendahnya komunikasi terapeutik yang dilakukan oleh perawat berdampak terhadap ketidakpuasan pasien. Hal ini terlihat dengan penelitian yang dilakukan Rosensttein dalam Nasir, menemukan bahwa ketidakpuasan hasil perawatan disebabkan oleh komunikasi perawat dan dokter serta staf penunjang. ${ }^{4}$

Pelayanan keperawatan masih sering mendapatkan keluhan dari masyarakat, terutama sikap dan kemampuan perawat dalam memberikan asuhan keperawatan kepada pasien. Tidak jarang terjadi konflik antara perawat dengan pasien sebagai akibat dari komunikasi yang tidak jelas atau tidak komunikatif sehingga menimbulkan kekecewaan dan ketidakpuasan serta kepercayaan yang rendah dari pasien. Hal ini sesuai dengan teori pencapaian tujuan menurut King dalam Nursalam, bahwa komunikasi mendukung penetapan bersama antara perawat dan pasien dalam mencapai kepuasan. Kepuasan merupakan perasaan senang atau kecewa seseorang yang muncul setelah membandingkan antara persepsi atau kesannya terhadap kinerja atau hasil suatu produk dan harapan-harapannya. ${ }^{7}$

Kepuasan klien merupakan hal utama yang perlu diprioritaskan oleh rumah sakit agar dapat bertahan, bersaing dan mempertahankan pasar 
yang sudah ada karena rumah sakit merupakan badan usaha yang bergerak dibidang jasa pelayanan kesehatan. Menurut laporan data Sensus Nasional tahun 2010 dalam Mowen, pelayanan kesehatan untuk rawat inap yang banyak dimanfaatkan adalah rumah sakit pemerintah adalah $(37,1 \%)$ dan rumah sakit swasta (34,3\%) sisanya adalah rumah sakit bersalin dan puskesmas, sedangkan untuk pelayanan komunikasi terapeutik disimpulkan bahwa ketidakpuasan dari pelayanan komunikasi terapeutik rumah sakit pemerintah dan rumah sakit swasta untuk rawat jalan dan rawat inap semakin meningkat. Kepuasan pelayanan komunikasi terapeutik di rumah sakit pemerintah secara umum lebih rendah dibandingkan dengan rumah sakit swasta. ${ }^{8}$

Terciptanya kepuasan pasien terhadap pelayanan perawat mempunyai hubungan yang erat dalam mendorong semangat dan usaha pasien untuk segera sembuh dari sakitnya. Beberapa alasan mengapa kepuasan pasien perlu dilakukan survei, antara lain: alasan yang pertama adalah penilaian kepuasan pasien mengandung informasi yang bermanfaat mengenai struktur, proses dan pelayanan, disamping itu penilaian tingkat kepuasan pasien merupakan tingkat evaluasi yang unik. Alasan yang kedua adalah bahwa tingkat kepuasan pasien mempunyai sifat produktif mengenai bagaimana pasien akan berperilaku. ${ }^{9}$

Hal ini didukung oleh penelitian Jakson dalam Renaldis IMS, tingkat Kepuasan Pasien Rawat Inap Terhadap Pelayanan Keperawatan di Rumah Sakit Umum Estomihi Medan didapat kepuasan pasien rawat inap adalah cukup puas (52,5\%), pasien yang merasa puas (35\%), dan kurang puas $(12,5 \%)$. Sitorus dalam Renaldis IMS, dengan penelitiannya tentang kepuasan klien dan keluarga menunjukan bahwa tingkat kepuasan dengan ketegori baik (16,9\%), kategori sedang (81,5\%) dan kategori kurang (1,55\%). Penelitian Dermawan dalam Renaldis IMS dengan judul hubungan pelaksanaan komunikasi terapeutik dengan kepuasan klien dalam mendapatkan pelayanan keperawatan di instalasi gawat darurat RSUD Dr Soedarso Pontianak Kalimantan Barat didapatkan responden sebanyak 108 orang didapat kepuasan klien selama dirawat klien merasa puas (66,7\%). Seorang klien yang tidak puas, akan menghasilkan sikap atau perilaku tidak patuh pada seluruh prosedur keperawatan dan prosedur medis misalnya menolak pemasangan infus, menolak meminum obat, menolak untuk dikompres panas atau dingin, dan lain-lain. Akhirnya klien akan meninggalkan rumah sakit dan mencari jasa pelayanan yang bermutu di tempat yang lain. Oleh sebab itu sudah saatnya kepuasaan klien menjadi bagian integral dalam misi dan tujuan profesi keperawatan karena semakin meningkatnya intensitas kompetensi global dan domestik, serta berubahnya preferensi dan perilaku dari klien untuk mencari pelayanan jasa keperawatan yang bermutu. $^{3}$

Berdasarkan data di Rumah Sakit Grha Permata Ibu Kota Depok, diperoleh pada tahun 2015 rata-rata tingkat pengguna tempat tidur (Bed Occupacy Rate/BOR) sebesar 36.04\%. Rata-rata lama rawatan (Average Length of Stay/LOS) sebesar 2.91 hari, rata-rata tempat tidur tidak ditempati saat terisi berikutnya (Turn Over Interval/TOI) sebesar 5.12 hari. Hasil tersebut memberikan gambaran tidak tercapainya standar ideal yang ditetapkan departemen kesehatan, juga dapat memberikan gambaran pelayanan yang diberikan dapat dikatakan kurang memuaskan.

Hasil survey kepuasan pasien yang peneliti lakukan pada bulan Mei 2016 dengan mewawancari 10 pasien rawat inap, didapatkan 8 pasien mengatakan ada perawat yang dalam melakukan pengukuran tanda vital, misalnya: tidak menanyakan identitasnya terlebih dahulu, tetapi langsung menarik tangan pasien dan melakukan pengukuran tekanan darah, mengukur suhu dan menghitung nadi pasien, serta tidak memberikan penjelasan prosedur yang akan dilakukan, pasien merasa bahwa pelayanan perawat kurang memuaskan pasien, sehingga menimbulkan komplain dari pasien yang di rawat inap.

Selain itu dari hasil pengamatan peneliti, sebagian perawat dalam merawat pasien yang tidak sadar, kurang memperlakukan seperti pasien yang sadar, sehingga berbicara menyinggung perasaan pasien, atau bahkan membicarakan kejelakan teman lain, padahal pasien yang tidak sadar dapat mendengar semua pembicaraan perawat. Hal ini perawat kurang mempraktekkan komunikasi yang bersifat menyembuhkan (terapeutik). Padahal komunikasi terapeutik yang baik akan menciptakan hubungan saling percaya antara perawat dan pasien. Dengan demikian, pasien akan merasa puas dan nyaman terhadap pelayanan yang diberikan perawat sehingga meningkatkan semangat dan motivasi pasien untuk sembuh. Berdasarkan latar belakang dan permasalahan yang ada, tujuan penelitian ini adalah untuk mengetahui hubungan komunikasi terapeutik perawat dengan kepuasan pasien rawat inap di Rumah Sakit Grha Permata Ibu Depok tahun 2016.

\section{Metode}

Jenis penelitian ini adalah penelitian kuantitatif dengan desain penelitian cross 
sectional yaitu pengumpulan data penelitian yang dilaksanakan sekaligus pada suatu saat (point time approach), artinya data penelitian yang dilaksanakan sekaligus pada suatu saat, ${ }^{10}$ variabel dependen dan variabel independen diukur dalam waktu yang bersamaan. Penelitian ini menggunakan instrumen atau metode angket atau kuesioner.

Populasi dalam penelitian ini adalah seluruh seluruh pasien rawat inap di Rumah Sakit Grha Permata Ibu Depok. Teknik pengambilan sampel dalam penelitian ini adalah Accidental Sampling. Accidental sampling adalah metode pengambilan sampel dengan memilih siapa yang kebetulan ada/dijumpai. ${ }^{11}$ Didapatkan sampel selama penelitian dari tanggal 11-24 Juli 2016 sebanyak 40 pasien. Sampel yang diambil adalah responden yang memenuhi kriteria inklusi. Kriteria inklusi dalam penelitian ini adalah pasien rawat inap di Rumah Sakit Grha Permata Ibu dan bersedia menjadi responden. Kriteria non inklusi dalam penelitian ini adalah bukan pasien rawat inap di Rumah Sakit Grha Permata Ibu dan tidak bersedia menjadi responden. Sedangkan kriteria eksklusi dalam penelitian ini tidak ada, karena semua target sampel memenuhi kriteria inklusi dan semua data primer terisi lengkap oleh responden melalui kuesioner.

Data yang digunakan adalah data primer, yaitu sumber-sumber dasar yang terdiri dari buktibukti atau saksi utama dari kejadian objek yang diteliti dan gejala yang terjadi dilapangan. ${ }^{12}$ Data primer diperoleh secara langsung dari sumbernya dan diperoleh dari jawaban atas pertanyaan yang disediakan melalui pengisian kuesioner oleh pasien rawat inap di Rumah Sakit Grha Permata Ibu Depok. Selain itu terdapat data sekunder yang merupakan data diperoleh dari catatan atau dokumen yang berasal dari Rumah Sakit Grha Permata Ibu Depok, serta data lainnya yang dianggap relevan dengan tujuan penelitian. Uji instrumen penelitian dilakukan dengan menggunakan uji validitas dan reliabilitas. Hasil pengukuran validitas dan reliabilitas variabel komunikasi terapeutik perawat rawat inap, dari 25 pernyataan kuesioner hanya 23 pernyataan kuesioner yang memenuhi syarat atau valid dan reliabel yaitu nilai $r_{\text {hitung }}>r_{\text {tabel. }}$ Sedangkan hasil pengukuran validitas dan reliabilitas variabel kepuasan pasien rawat inap, dari 15 pernyataan kuesioner hanya 14 pernyataan kuesioner yang memenuhi syarat atau valid dan reliabel yaitu nilai $r_{\text {hitung }}>r_{\text {tabel. }}$

Dalam penelitian ini kuesioner dibagikan dan diisi langsung oleh responden, sementara untuk pengumpulan data dilakukan setelah kuesioner telah diisi oleh responden. Langkah pengumpulan data penelitian ini dilakukan dengan cara: (a) Membuat surat permohonan izin pengambilan data dan izin penelitian pada Rumah Sakit Grha Permata Ibu Depok yang dikeluarkan oleh BAAK STIKIM; (b) Mengajukan izin penelitian kepada Rumah Sakit Grha Permata Ibu Depok untuk mengadakan penelitian; (c) Mengadakan pengkajian data yang relevan yang dapat mendukung penelitian ini pada Rumah Sakit Grha Permata Ibu Depok; (d) Memberikan penjelasan singkat tentang rencana kegiatan penelitian dan tujuan penelitian kepada responden yang setuju berpartisipasi dalam penelitian ini; (e) Responden diberi kuesioner untuk diisi sesuai dengan petunjuk yang telah diberikan dalam format pertanyaan kuesioner; (f) Responden diarahkan untuk mengisi semua pertanyaan yang telah disiapkan sesuai dengan kejadian yang benar terjadi kepada responden sehingga mengurangi terjadinya bias antara hasil penelitian dengan kejadian dilapangan; (g) Apabila ada pertanyaan yang kurang dimengerti dapat ditanyakan kepada peneliti; dan (h) Langkah terakhir setelah kuesioner dikumpulkan, dilakukan pengolahan data dan analisis data.

Pengolahan data dilakukan melalui proses editing data, coding, cleaning data dan prosecing. Data diolah secara komputerisasi yang hasilnya meliputi analisis univariat menjelaskan atau mendeskripsikan karakteristik setiap variabel penelitian, dan analisis bivariat dengan menggunakan uji statistik Chi-Square dengan derajat kemaknaan sebesar 5\%. Kemudian data disajikan dalam bentuk tabel dan narasi.

\section{Hasil}

Tabel 1. Distribusi Responden pada Variabel Komunikasi Terapeutik Perawat dan Kepuasan Pasien Rawat Inap Rumah Sakit Grha Permata Ibu Depok

\begin{tabular}{clcc}
\hline Variabel & Kategori & n & \% \\
\hline \multirow{2}{*}{ Kepemimpinan } & Kurang Baik & 17 & 42,5 \\
& Baik & 23 & 57,5 \\
\multirow{2}{*}{ Kepuasan } & Kurang Puas & 26 & 60,5 \\
& Puas & 17 & 39,5 \\
\hline
\end{tabular}

Hasil analisis univariat berada pada tabel 1. yang menunjukkan bahwa lebih banyak responden menilai perawat rawat inap di Rumah Sakit Grha Permata Ibu Depok tahun 2016 memiliki komunikasi terapeutik yang baik, yaitu sebanyak 23 responden dengan persentase sebesar 57,5\%. Sedangkan pada variabel kepuasan pasien rawat inap, lebih banyak pasien rawat inap di Rumah Sakit Grha Permata Ibu Depok tahun 2016 merasa puas terhadap pelayanan rawat inap, yaitu 
sebanyak 24 responden dengan persentase sebesar

$60,0 \%$.

Tabel 2. Hubungan Komunikasi Terapeutik Perawat terhadap Kepuasan Pasien Rawat Inap di Rumah Sakit Grha Permata Ibu Depok

\begin{tabular}{|c|c|c|c|c|c|c|c|}
\hline \multirow{3}{*}{ Variabel } & \multirow{3}{*}{ Kategori } & \multicolumn{4}{|c|}{ Kepuasan } & \multirow{3}{*}{ P Value } & \multirow{3}{*}{ OR } \\
\hline & & \multirow{2}{*}{$\begin{array}{c}\text { Kurang } \\
\mathbf{N} \\
\end{array}$} & \multirow{2}{*}{$\begin{array}{c}\text { Puas } \\
\%\end{array}$} & \multicolumn{2}{|c|}{ Puas } & & \\
\hline & & & & $\mathbf{N}$ & $\%$ & & \\
\hline Komunikasi & Kurang Baik & 11 & 64,7 & 6 & 35,3 & 0016 & 6,600 \\
\hline Terapeutik & Baik & 5 & 21,7 & 18 & 78,3 & 0,016 & $(1,621-26,871)$ \\
\hline
\end{tabular}

Tabel 2. diketahui bahwa 18 responden dengan persentase $78,3 \%$ mendapatkan komunikasi terapeutik perawat yang baik dan merasa puas pada pelayanan rawat inap di Rumah Sakit Grha Permata Ibu Depok. Sedangkan ada 11 responden dengan persentase $64,7 \%$ mendapatkan komunikasi terapeutik perawat yang kurang baik dan merasa kurang puas pada pelayanan rawat inap di Rumah Sakit Grha Permata Ibu Depok. Hasil uji hipotesis chi square diperoleh p-value sebesar 0,016, maka dapat disimpulkan bahwa ada hubungan komunikasi terapeutik perawat terhadap kepuasan pasien rawat inap di Rumah Sakit Grha Permata Ibu Depok tahun 2016. Selain itu, diperoleh nilai Odds Ratio (OR) sebesar 6,600, artinya responden yang mendapatkan komunikasi terapeutik perawat yang baik mempunyai peluang 6,600 (7) kali lebih besar untuk merasakan puas pada pelayanan rawat inap di Rumah Sakit Grha Permata Ibu Depok dibandingkan dengan responden yang mendapatkan komunikasi terapeutik perawat yang kurang baik.

\section{Pembahasan}

Penelitian ini tidak lepas dari keterbatasan, diantaranya keterbatasan pengetahuan yang dimiliki oleh penulis, biaya, waktu penelitian yang penulis lakukan sangat singkat, dan lain-lain. Adapun beberapa kelemahan penelitian ini adalah sebagai berikut : (1) Pilihan variabel terbatas pada variabel yang ada sehingga variabel penelitian ini disesuaikan dengan data yang sudah ada; (2) Penelitian ini hanya mencakup satu tempat penelitian, maka hasil penelitian ini belum tentu dapat digeneralisasikan di institusi lain; (3) Keterbatasan sumber pustaka dan waktu yang singkat menyebabkan penelitian ini tidak banyak membandingkan teori-teori atau pendapat yang telah ada dengan hasil penelitian; dan (4) Pengetahuan dan biaya penulis masih terbatas sehingga penelitian ini masih jauh dari sempurna. Pengumpulan data dalam penelitian ini menggunakan kuesioner, jadi kebenaran hasil penelitian tergantung pada kejujuran responden mengisi kuesioner. Peneliti tidak melakukan wawancara secara mendalam kepada para responden untuk mendapatkan informasi yang lebih mendalam mengenai faktor yang mempengaruhi kepuasan pasien rawat inap. Hal ini disebabkan karena keterbatasan waktu sehingga data dalam penelitian ini hanya terbatas pada jawaban di dalam kuisioner saja. Meskipun demikian, peneliti berusaha untuk membahas hasil penelitian semaksimal mungkin sesuai dengan kemampuan yang ada pada peneliti agar penelitian ini dapat bermanfaat.

\section{Komunikasi Terapeutik Perawat}

Komunikasi adalah proses pernyataan antar manusia, yang dinyatakan adalah pikiran atau perasaan seseorang kepada orang lain dengan menggunakan bahasa sebagai alat penyalurannya. Komunikasi merupakan proses belajar seumur hidup bagi perawat. Perawat terus berhubungan dengan pasien dan keluarganya sejak kelahiran sampai kematian. Oleh karena itu, dibutuhkan pembentukan komunikasi terapeutik. Perawat berkomunikasi dengan orang lain yang mengalami tekanan, yaitu: pasien, keluarga, dan teman sejawat. $^{3}$ Untuk itu perawat memerlukan keterampilan intelektual, teknikal yang tercermin dalam perilaku berkomunikasi secara terapeutik dengan orang lain. Perawat yang memiliki keterampilan berkomunikasi secara terapeutik tidak akan hanya mudah menjalin hubungan rasa percaya dengan klien, tetapi juga mencegah terjadinya masalah legal, memberikan kepuasan profesional dalam pelayanan keperawatan, dan meningkatkan citra profesi serta citra rumah sakit. $^{4}$

Berdasarkan hasil penelitian didapatkan mayoritas perawat rawat inap di Rumah Sakit Grha Permata Ibu Depok tahun 2016 memiliki komunikasi terapeutik yang baik, yaitu sebanyak 23 responden dengan persentase sebesar 57,5\%.

Penelitian tentang komunikasi terapeutik yang terdahulu, diantaranya penelitian tentang hubungan karakteristik individu perawat dan organisasi dengan penerapan komunikasi terapeutik di ruang rawat inap Rumah Sakit Persahabatan Jakarta yang dilakukan pada 147 perawat pelaksana yang bertugas, menunjukkan bahwa penerapan komunikasi masih relatif kurang (46,3\%), baik (35,2\%), dan cukup (18,5\%). Hal 
ini didukung penelitian terdahulu oleh Randra dalam Kencana, dengan penelitian penerapan komunikasi terapeutik perawat dalam memberikan tindakan keperawatan di RSIA Budhi Asih Jakarta dari 36 sampel bahwa responden melakukan komunikasi dengan baik (60\%), dan kurang baik (40\%). ${ }^{13}$

Salah satu hal yang dilakukan perawat dalam menjaga kerja sama yang baik dengan pasien dalam membantu kesembuhan pasien dan memenuhi kebutuhan kesehatan pasien, maupun dengan tenaga kesehatan lain dalam rangka membantu mengatasi masalah pasien adalah dengan berkomunikasi. Dengan berkomunikasi perawat dapat mendengarkan perasaan pasien dan menjelaskan prosedur tindakan keperawatan. Hubungan saling memberi dan menerima antara perawat dan pasien dalam pelayanan keperawatan disebut sebagai komunikasi terapeutik perawat yang merupakan komunikasi profesional dalam keperawatan. $^{4}$

Menurut asumsi peneliti bahwa masih adanya perawat rawat inap di Rumah Sakit Grha Permata Ibu Depok yang dalam melakukan pengukuran tanda vital, misalnya: tidak menanyakan identitasnya terlebih dahulu, tetapi langsung menarik tangan pasien dan melakukan pengukuran tekanan darah, mengukur suhu dan menghitung nadi pasien, serta tidak memberikan penjelasan prosedur yang akan dilakukan. Selain itu dari hasil pengamatan peneliti, sebagian perawat dalam merawat pasien yang tidak sadar, kurang memperlakukan seperti pasien yang sadar, sehingga berbicara menyinggung perasaan pasien, atau bahkan membicarakan kejelakan teman lain, padahal pasien yang tidak sadar dapat mendengar semua pembicaraan perawat.

\section{Kepuas an Pasien}

Kepuasan konsumen adalah sejauh mana manfaat sebuah produk dirasakan (perceived) sesuai dengan apa yang diharapkan pasien. Kotler, mengatakan bahwa kepuasan konsumen merupakan tingkat perasaan seseorang setelah membandingkan antara kepuasan produk yang ia rasakan dengan harapannya. Menurut Tse dan Wilson dalam Nasution, kepuasan atau ketidakpuasan konsumen adalah respon terhadap evaluasi ketidaksesuaian atau diskonfirmasi yang dirasakan antara harapan sebelumnya dan kepuasan aktual produk yang dirasakan setelah pemakaian. ${ }^{14}$ Westbrook \& Reilly dalam Tjiptono yang dikutip dari tesis Ambarita, mengemukakan bahwa kepuasan konsumen merupakan respon emosional terhadap pengalaman yang berkaitan dengan produk atau jasa yang dibeli. Pendapat lain mengatakan bahwa kepuasan konsumen sangat bergantung kepada persepsi dan harapan konsumen. ${ }^{15}$

Berdasarkan hasil penelitian didapatkan mayoritas pasien rawat inap di Rumah Sakit Grha Permata Ibu Depok tahun 2016 merasa puas terhadap pelayanan rawat inap, yaitu sebanyak 24 responden dengan persentase sebesar 60,0\%.

Hal ini didukung oleh penelitian Jakson dalam Renaldis IMS, tingkat Kepuasan Pasien Rawat Inap Terhadap Pelayanan Keperawatan di Rumah Sakit Umum Estomihi Medan didapat kepuasan pasien rawat inap adalah cukup puas (52,5\%), pasien yang merasa puas (35\%), dan kurang puas (12,5\%). Sitorus dalam Renaldis IMS, dengan penelitiannya tentang kepuasan klien dan keluarga menunjukan bahwa tingkat kepuasan dengan ketegori baik (16,9\%), kategori sedang (81,5\%) dan kategori kurang $(1,55 \%){ }^{3}$

Terciptanya kepuasan pasien terhadap pelayanan perawat mempunyai hubungan yang erat dalam mendorong semangat dan usaha pasien untuk segera sembuh dari sakitnya. Beberapa alasan mengapa kepuasan pasien perlu dilakukan survei, antara lain: alasan yang pertama adalah penilaian kepuasan pasien mengandung informasi yang bermanfaat mengenai struktur, proses dan pelayanan, disamping itu penilaian tingkat kepuasan pasien merupakan tingkat evaluasi yang unik. Alasan yang kedua adalah bahwa tingkat kepuasan pasien mempunyai sifat produktif mengenai bagaimana pasien akan berperilaku. ${ }^{9}$

Peneliti berasumsi bahwa derajat kepuasan terhadap pelayanan pasti didapatkan dari pelayanan yang diberikan rumah sakit terhadap pasiennya. Pasien merasa pelayanan keperawatan yang kurang memuaskan dapat menimbulkan komplain dari pasien tersebut. Untuk melihat seberapa besar derajat kepuasan pasien tidak hanya dari survey kepuasan tetapi dapat dilihat pada banyaknya kompain yang diutarakan pasien kepada manajemen rumah sakit.

\section{Hubungan Komunikasi Terapeutik Perawat Terhadap Kepuasan Pasien}

Komunikasi tidak hanya sekedar alat untuk berbicara dengan klien, namun komunikasi perawat dengan perawat maupun perawat dengan pasien memiliki hubungan terapeutik yang bertujuan untuk kesembuhan klien. ${ }^{5}$ Perawat yang memiliki keterampilan berkomunikasi terapeutik tidak saja akan mudah membina hubungan saling percaya dengan klien, tetapi juga dapat mencegah terjadinya masalah legal etik, serta dapat memberikan kepuasan profesional dalam pelayanan keperawatan, meningkatkan citra profesi keperawatan dan citra rumah sakit dalam memberikan pelayanan. Ada dua jenis komunikasi 
yaitu komunikasi verbal, dan komunikasi non verbal yang dimanifestasikan secara terapeutik. ${ }^{6}$

Komunikasi menjadi tidak efektif karena kesalahan dalam menafsirkan pesan yang diterimanya. Selain itu komunikasi yang kurang baik dari perawat akan berdampak buruk diantaranya yaitu, terjadi kesalahpahaman antara perawat dengan pasien maupun keluarganya dan akan menimbulkan ketidakpuasan pasien. Pasien akan merasa terhambat untuk menyampaikan permasalahan yang dialami karena perawat sering menyampaikan dengan pertanyaan tertutup yang hanya membutuhkan jawaban "ya" dan "tidak". ${ }^{16}$

Kepuasan pasien merupakan suatu situasi dimana pasien dan keluarga mengganggap bahwa biaya yang dikeluarkan sesuai dengan kualitas pelayanan yang diterima dan tingkat kemajuan kondisi kesehatan yang dialaminya. Mereka merasa pelayanan yang diberikan merupakan penghargaan terhadap diri dan kehormatan yang dimilikinya. Selain itu mereka merasakan manfaat lain setelah dirawat yaitu pengetahuan tentang penyakit dan dirinya menjadi bertambah. Namun sebaliknya, pasien jarang untuk mencoba mempertimbangkan apakah pelayanan keperawatan yang diberikan itu merupakan upaya yang efektif dan efisien dilihat dari segi waktu, tenaga, dan sumber daya yang digunakan. ${ }^{17}$

Berdasarkan hasil penelitian didapatkan 18 responden dengan persentase $78,3 \%$ mendapatkan komunikasi terapeutik perawat rawat inap yang baik dan merasa puas pada pelayanan rawat inap di Rumah Sakit Grha Permata Ibu Depok. Sedangkan ada 11 responden dengan persentase 64,7\% mendapatkan komunikasi terapeutik perawat rawat inap yang kurang baik dan merasa kurang puas pada pelayanan rawat inap di Rumah Sakit Grha Permata Ibu Depok.

Hasil uji hipotesis chi square diperoleh pvalue sebesar 0,016, maka dapat disimpulkan bahwa ada hubungan komunikasi terapeutik perawat terhadap kepuasan pasien rawat inap di Rumah Sakit Grha Permata Ibu Depok tahun 2016. Selain itu, diperoleh nilai Odds Ratio (OR) sebesar 6,600, artinya responden yang mendapatkan komunikasi terapeutik perawat yang baik mempunyai peluang 6,600 (7) kali lebih besar untuk merasakan puas pada pelayanan rawat inap di Rumah Sakit Grha Permata Ibu Depok dibandingkan dengan responden yang mendapatkan komunikasi terapeutik perawat yang kurang baik.

Ada beberapa kemungkinan kurang berhasilnya komunikasi terapeutik perawat pada klien diantaranya dipengaruhi oleh kurangnya pengetahuan perawat dalam komunikasi terapeutik, sikap perawat, tingkat pendidikan, pengalaman, lingkungan, jumlah tenaga yang kurang dan lain-lain. Rendahnya komunikasi terapeutik yang dilakukan oleh perawat berdampak terhadap ketidakpuasan pasien. Hal ini terlihat dengan penelitian yang dilakukan Rosensttein dalam Nasir, menemukan bahwa ketidakpuasan hasil perawatan disebabkan oleh komunikasi perawat dan dokter serta staf penunjang. ${ }^{4}$

Penelitian terdahulu pada Dermawan dalam Renaldis IMS, mengenai hubungan pelaksanaan komunikasi terapeutik dengan kepuasan klien dalam mendapatkan pelayanan keperawatan di instalasi gawat darurat RSUD Dr Soedarso Pontianak Kalimantan Barat didapatkan responden sebanyak 108 orang didapat kepuasan klien selama dirawat klien merasa puas (66.7\%). Seorang klien yang tidak puas, akan menghasilkan sikap atau perilaku tidak patuh pada seluruh prosedur keperawatan dan prosedur medis misalnya menolak pemasangan infus, menolak meminum obat, menolak untuk dikompres panas atau dingin, dan lain-lain. Akhirnya klien akan meninggalkan Rumah Sakit dan mencari jasa pelayanan yang bermutu di tempat yang lain. Oleh sebab itu sudah saatnya kepuasaan klien menjadi bagian integral dalam misi dan tujuan profesi keperawatan karena semakin meningkatnya intensitas kompetensi global dan domestik, serta berubahnya preferensi dan perilaku dari klien untuk mencari pelayanan jasa keperawatan yang bermutu. $^{3}$

Menurut asumsi peneliti masih ada perawat rawat inap di Rumah Sakit Grha Permata Ibu Depok yang dalam melakukan pengukuran tanda vital, misalnya: tidak menanyakan identitasnya terlebih dahulu, tetapi langsung menarik tangan pasien dan melakukan pengukuran tekanan darah, mengukur suhu dan menghitung nadi pasien, serta tidak memberikan penjelasan prosedur yang akan dilakukan. Selain itu dari hasil pengamatan peneliti, sebagian perawat dalam merawat pasien yang tidak sadar, kurang memperlakukan seperti pasien yang sadar, sehingga berbicara menyinggung perasaan pasien, atau bahkan membicarakan kejelakan teman lain, padahal pasien yang tidak sadar dapat mendengar semua pembicaraan perawat.

Hal tersebut membuat pasien merasa bahwa pelayanan perawat kurang memuaskan pasien, sehingga menimbulkan komplain dari pasien yang di rawat inap, pasien merasa bahwa pelayanan perawat kurang memuaskan pasien, sehingga menimbulkan komplain dari pasien yang di rawat inap. Komunikasi antar perawat dan klien memiliki hubungan terapeutik yang bertujuan untuk kesembuhan klien. Terciptanya komunikasi 
terapeutik yang baik akan menciptakan hubungan saling percaya antara perawat dan pasien. Dengan demikian, pasien akan merasa puas dan nyaman terhadap pelayanan yang diberikan perawat sehingga meningkatkan semangat dan motivasi pasien untuk sembuh.

\section{Kesimpulan}

Berdasarkan hasil penelitian mengenai diperoleh kesimpulan bahwa lebih banyak perawat rawat inap di Rumah Sakit Grha Permata Ibu Depok tahun 2016 memiliki komunikasi terapeutik yang baik, dan pasien rawat inap di Rumah Sakit Grha Permata Ibu Depok tahun 2016 merasa puas terhadap pelayanan rawat inap. Ada hubungan komunikasi terapeutik perawat terhadap kepuasan pasien rawat inap di Rumah Sakit Grha Permata Ibu Depok tahun 2016

\section{Saran}

Berdasarkan temuan, maka saran dari penelitian ini adalah diharapkan perawat rawat inap di Rumah Sakit Grha Permata Ibu Depok dalam melakukan pengukuran tanda vital, memberikan penjelasan prosedur yang akan dilakukan dikomunikasikan terlebih dahulu dengan pasiennya serta diharapkan untuk meningkatkan kemampuan mengenai komunikasi terapeutik yang baik dengan mengikuti pelatihan, workshop, bimbingan teknis khusus maupun seminar yang tidak disediakan oleh diklat Rumah Sakit Grha Permata Ibu Depok. Diharapkan manajemen atau Diklat Rumah Sakit Grha Permata Ibu Depok untuk mendukung serta

4. Nasir A, Muhith A, Sajidin M, dan Mubarak WI. Komunikasi dalam Keperawatan; Teori dan Aplikasi. Jakarta: Salemba Medika; 2009.

5. Potter dan Perry. Buku Ajar Fundamental Keperawatan; Konsep, Proses \& Praktik, ed. 4. Jakarta: EGC; 2010.

6. Praptiwi A. Pengelolaan Kepuasan Pelanggan Dalam Pelayanan Kesehatan, Materi Disampaikan Pada Pelatihan Dan Workshop Manajemen Keperawatan di RSUD 45 Kuningan. [Skripsi]. Bandung: Fakultas Ilmu Keperawatan Universitas Padjadjaran; 2009.

7. Nursalam. Manajemen Keperawatan; Aplikasi dalam Praktik Keperawatan Profesional. Jakarta: Salemba Medika; 2012.

8. Mowen. Pengukuran Tingkat Kepuasan Pelanggan. Jakarta: Rineka Cipta; 2014.

9. Heriandi. Faktor-faktor Yang Berhubungan Dengan Tingkat Kepuasan Pasien. [Skripsi]. Manado: Program Studi Ilmu Keperawatan Fakultas Kedokteran Universitas Sam Ratulangi; 2016.

10. Notoatmodjo S. Metodologi Penelitian Kesehatan. Jakarta: Rineka Cipta; 2010 memfasilitasi perawat dalam meningkatkan komunikasi terapeutiknya, dengan mengirimkan perawatnya dalam pelatihan, workshop, bimbingan teknis khusus maupun seminar atau mengadakan pelatihan secara internal mengenai komunikasi terapeutik yang baik.

Diharapkan pada peneliti selanjutnya untuk meneliti selain dari variabel yang diteliti pada penelitian ini, masih banyak variabel yang mempengaruhi kepuasan pasien. Diharapkan untuk menganalisis lebih mendalam, sampai pada permodelan multivariat, sehingga dapat diketahui indikator dari variabel komunikasi terapeutik yang mana paling mendukung pengukuran komunikasi terapeutik untuk berpengaruh terhadap kepuasan pasien. Selain itu dapat dilakukan dengan melakukan penelitian mix method yang disertai dengan penelitian kualitatif sehingga hasil penelitian lebih teranalisis lebih mendalam.

\section{Daftar Pus taka}

1. Nurachmah. Manajemen yang Bermutu di Rumah Sakit. Jakarta: Erlangga; 2011.

2. Trimumpuni EN. Analisis Pengaruh Persepsi Mutu Pelayanan Asuhan Keperawatan Terhadap Kepuasan Klien Rawat Inap di RSU Puri Asih Salatiga. [Tesis]. Semarang: Program Pascasarjana Universitas Diponegoro; 2009.

3. Reneldis IMS. Gambaran Kepuasan Pasien Berdasarkan Komunikasi Terapeutik Perawat dalam Memberikan Pelayanan Keperawatan di Ruang Lontara II RSUP DR Wahidin Sudirohusodo Makassar. [Skripsi]. Makassar: Program Studi Ilmu Keperawatan Fakultas Kedokteran Universitas Hasanuddin; 2010.

11. Sugiyono. Metode Penelitian Kombinasi (Mixed Methods). Bandung: Alfabeta; 2012

12. Sumantri, Arif. Metode Penelitian Kesehatan. Edisi pertama. Jakarta: Kencana; 2011.

13. Kencana. Persepsi Pasien Terhadap Perilaku Komunikasi Perawat di Rumah Sakit Persahabatan Jakarta. [Skripsi] Jakarta: Program Studi Ilmu Keperawatan Sekolah Tinggi Ilmu Kesehatan Binawan; 2014.

14. Nasution. Mengukur Kepuasan Pelanggan. Jakarta: Raja Grafindo Persada; 2012.

15. Ambarita. Analisis Faktor yang Berhubungan dengan Kepuasan Pasien Rawat Inap di Rumah Sakit Islam Surakarta. [Tesis]. Surakarta: Program Pascasarjana Keperawatan Universitas Muhammadiyah Surakarta; 2013.

16. Arwani. Komunikasi dalam Keperawatan. Jakarta: EGC; 2012.

17. Mapa AR. Hubungan Persepsi Pasien Tentang Komunikasi Perawat Dengan Kepuasan Pasien Terhadap Komunikasi di RSUP DR. Soeradji Tirtonegoro Klaten. [Skripsi]. Surakarta: Universitas Muhammadiyah Surakarta; 2009. 